\title{
The Environmental Consequences Concerning the Use of Timber in the Built Environment
}

\author{
Callum Aidan Stephen Hill* \\ JCH Industrial Ecology Ltd., Bangor, United Kingdom
}

The use of timber in the built environment provides environmental benefits which arise dues to the substitution of higher impact materials, the storage of sequestered atmospheric carbon in long-life products and the recovery of inherent energy in the material at the end of life. This manuscript explores the issues that determine how embodied energy and global warming potential are calculated and reported. The article discusses the literature which compares the use of timber in the built environment and other materials in life cycle assessment studies. The issue of how sequestered carbon should be dealt with is also discussed. End of life considerations are also addressed.

OPEN ACCESS

Edited by:

Dimitrios Kraniotis,

Oslo Metropolitan University, Norway

Reviewed by:

Sanja Stevanovic,

Serbian Academy of Sciences and

Arts, Serbia

Christian Brischke,

University of Göttingen, Germany Dimitris Kaziolas,

International Hellenic

University, Greece

*Correspondence:

Callum Aidan Stephen Hill enquiries@jchindustrial.co.uk

Specialty section:

This article was submitted to Sustainable Design and Construction,

a section of the journal Frontiers in Built Environment

Received: 24 April 2019 Accepted: 10 October 2019 Published: 25 October 2019

Citation:

Hill CAS (2019) The Environmental Consequences Concerning the Use of Timber in the Built Environment.

Front. Built Environ. 5:129. doi: 10.3389/fbuil.2019.00129
Keywords: life cycle (impact) assessment, carbon, global warming potential (GWP), timber, sequestered $\mathrm{CO}_{2}$

\section{INTRODUCTION}

According to the Intergovernmental Panel on Climate Change (IPCC), it is estimated that $40 \%$ of primary energy demand and $36 \%$ of $\mathrm{CO}_{2}$ emissions of industrialized countries are attributable to operational energy use in the built environment sector. If the embodied energy and greenhouse gas (GHG) emissions associated with construction materials are included, then these proportions are even higher. Broun and Menzies (2011) state that 60\% of extractions from the lithosphere are associated with the construction sector worldwide. In Europe, mineral extractions to supply the built environment average 4.8 tons per person per year and a total of 2.3 tons of materials are required per $\mathrm{m}^{2}$ of floor area in the Spanish construction sector (Bribián et al., 2011). But it should be noted that this is direct materials use only; the material intensity per unit service (all resources needed to produce these materials) is 6 tons per $\mathrm{m}^{2}$.

There are resource-use inefficiencies, with 850 million tons of waste are generated during the demolition process every year in Europe (De Schepper et al., 2014) and contingency-related overordering amounting to about $15 \%$ of materials subsequently being exported as waste (Monahan and Powell, 2011). However, the built environment sector has significant potential for mitigating climate change, both through reductions in operational energy, and by choosing appropriate construction materials with the lowest overall environmental impact (Suttie et al., 2009). By increasing the use of timber in construction, it is possible to mitigate against climate change with no cost penalty. The potential of timber in this regard is two-fold: (i) the benefits obtained by substituting higher embodied energy and embodied carbon materials and (ii) the potential climate change mitigation benefits derived from the storage of sequestered atmospheric carbon dioxide in long-life products.

\section{ENERGY AND CONSTRUCTION}

In order to properly assess the best materials choices for construction it is essential to analyse the total lifecycle energy use of a building (cumulative energy demand). This is a combination of the 
operational (or direct) as well as the embodied (or indirect) energy associated with the materials that are used in the structure. The whole lifecycle energy requirements are often referred to as the embodied energy of the building, but this should not be combined, but instead reported separately as the initial embodied energy (associated with the materials used), the recurring embodied energy (associated with maintenance and replacement of the building fabric), and the operational energy requirements (heating, cooling lighting, etc.). Materials choices may be based solely upon data related to the initial embodied energy, but pay little attention to the impact upon recurring embodied energy. This is bad practice and it is important to consider the whole lifecycle, including end of life.

One of the problems of using embodied energy data in decision processes is that the definitions vary. The embodied energy of a material or process is invariably defined as the primary energy used in manufacture. This usually means the primary energy used in the extraction of the raw ingredients from the environment, the energy used in manipulating these ingredients, transportation, and forming of those ingredients into the finished product until the point where it leaves the factory gate (cradle to gate). This excludes any subsequent operations beyond the factory gate, such as transport to site, or installation maintenance. This is covered by reporting the embodied energy for the lifecycle stages A1-A3 according to European Standard EN 15804 (2012), although this standard makes no direct reference to embodied energy. However, in some definitions of embodied energy, transport to the building site (lifecycle stage A4) along with the energy used on site for installation (A5) is also included. The units used are generally MJ (or $\mathrm{kWh}=3.6 \mathrm{MJ}$ ) for a stated mass, or volume of a material or product, or for a defined functional unit (such as $1 \mathrm{~m}^{2}$ of a wall element, with defined properties). It is important to be clear which stages of the lifecycle are included, because transport to the building site may have a significant impact on the embodied energy of the construction materials (Morel et al., 2001).

Some studies include the energy used for the maintenance of the product, which is reported in the use stage modules in EN 15804 (2012) (B1-B5) related to the building fabric. This is distinct from the initial embodied energy, which does not change once the product is manufactured and installed (Ramesh et al., 2010; Chau et al., 2015), although these values can change over time. In some cases, the energy associated with the disposal of a product at the end of a lifecycle is considered, which in EN 15804 (2012) is reported in modules C1-C4 and in some situations, module D. Although including the different lifecycle stages is not a problem (provided it is explicitly stated which stages are included in the analysis); however where this is not stated, problems will occur when trying to compare different products or materials. Consistency and transparency are essential.

Comparisons of embodied energy are only valid if primary energy has been used for the data, but delivered energy used for processing may be reported, in error. Primary energy is the energy measured at the natural resource level, which is the energy used to provide the end-use energy, including energy used in the extraction, transformation and distribution to the end-user, in addition to the inherent energy present in a fuel (Fay et al., 2000).
For a fuel, such as natural gas, this includes energy associated with prospecting, extracting, purification, and transportation to end-user, which can vary for different geographical regions and evolve over time (Smil, 2007). Even when primary energy is the data source, errors may occur because either the lower or higher heating values of primary energy sources may have be used, the use of renewable energy resources may not have been included, plus there are differences in the way that primary nuclear energy is calculated (Lenzen, 2008; Dixit et al., 2012).

The initial embodied energy of the materials used in the fabric of a building is usually not more that $30 \%$ of the total energy demand (embodied plus operational energy), although some studies state values in the region of $10-20 \%$ (Kotaji et al., 2003). For this reason, it is important to pay more attention to operational requirements. However, at a sector level initial embodied energy can be much higher than $30 \%$ of the total energy demand, where there is an increasing demand for buildings and retrofitting (Treloar et al., 2001). It is also important to note that as the trend for improving the operational energy efficiency continues, then the initial and recurring embodied energy will become more significant. Although endof-life energy use for demolition and disposal make a very small proportion of the whole lifecycle energy use of buildings, this may change over time as the buildings have lower energy demands (Winistorfer et al., 2005).

There is often confusion between the terms "embodied energy," which is associated with the production of a functional unit and the "inherent (or embedded) energy," which is a physical property of the material. For a timber product it is possible to recover the inherent energy at the end of its lifecycle, but the inherent energy of concrete is zero. Where the inherent energy is recoverable this may be reported as the higher heating value, or the lower heating value and if this is not explicitly stated, it is another potential source of error. The recovery of the inherent energy in timber at the end of the lifecycle is an important consideration when determining the environmental impact of the material. This information is usually reported in module D of EN 15804 (2012), but there is some debate as to where and how this should be properly reported. For example, the incineration of wood with energy at the end of lifecycle has a large benefit in terms of greenhouse gas (GHG) mitigation when substituting for coal as an energy source for electricity production, but this is not so clear when the grid is dominated by hydro-electric generation.

There is considerable variation in the reported initial embodied energies associated with structures. For example in the UK, Hammond and Jones (2008) reported an average of 5.3 $\mathrm{GJ} / \mathrm{m}^{2}$, and Asif et al. (2007) reported $3.25 \mathrm{GJ} / \mathrm{m}^{2}$ per $\mathrm{m}^{2}$ of habitable floor area. Other studies report 8-12 GJ/m² (Oka et al., 1993), or 1.3-7.3 GJ/m² (Nässén et al., 2007) interestingly, Nässén et al. (2007) found that there was nearly 90\% higher apparent embodied energy per $\mathrm{m}^{2}$ when a top down analysis was adopted, when compared with a bottom-up analyses. They reported that only $20 \%$ of this was attributable to the embodied energy of the materials. There have been claims of a strong correlation between capital cost and embodied energy at a building level, but this correlation was found to be very weak when examined at a materials level (Langston and Langston, 2008). 


\section{GLOBAL WARMING POTENTIAL (GWP)}

The characterization factor for reporting the impact of a good or service upon climate is known as global warming potential (GWP). This is calculated according to methods published by the Intergovernmental Panel on Climate Change (IPCC) and is usually reported for a 100 -year timeframe $\left(\mathrm{GWP}_{100}\right)$ with a characterization factor of $\mathrm{kg} \mathrm{CO}_{2}$ equivalents $\left(\mathrm{CO}_{2} \mathrm{e}\right)$. Carbon dioxide is referred to as a greenhouse gas (GHG) since it has a property called radiative forcing. In essence, radiative forcing means that a GHG intercepts infra-red radiation which is emitted from the surface of the planet and then re-radiates this energy in all directions, some back to the surface. This affects the balance between incoming solar radiation and results in an increase in the equilibrium temperature of the planet. Other GHGs have different magnitudes of radiative forcing compared to carbon dioxide and this can vary over time. For example, methane has a much higher level of radiative forcing compared to carbon dioxide, but over time this gas will break down through oxidation to form carbon dioxide and water. This means that the radiative forcing property of methane will reduce with time. Over a 100year time horizon methane has a radiative forcing of 28 times that of the same weight of $\mathrm{CO}_{2}$, but this is $84 \mathrm{x}$ that of $\mathrm{CO}_{2}$ over a 20-year time horizon (IPCC).

GWP data is currently reported as the climate change impact associated with the emissions of GHGs (directly and indirectly) associated with the manufacture of a product or service (lifecycle stages A1-A3). Other parts of the lifecycle may also be included and for a proper comparison to be made to inform the correct choice of materials for buildings, it is necessary to consider all stages of the lifecycle. For harvested wood products (HWPs) there are additional considerations regarding the impacts associated with forestry operations, which may include issues associated with land use change, as well as impacts upon soil carbon and the ecosystem services that forests provide, in addition to harvestable timber. Once the timber is harvested and transported to a processing facility it is then subjected to a range of operations, such as debarking, sawing, drying, machining, application of preservatives, etc., which all have associated GWP impacts. Generally speaking, the more operations involved then the higher is the GWP impact. However, there are many variables which can influence the GWP values reported for a specific class of HWP. These can include, primary energy mix of the local electricity grid, transportation distances and mode of transport, energy use for the kilning operation (gas, oil, electricity, and biomass), energy efficiency of the operations, etc. Where a processing facility produces multiple products, there are issues associated with the correct allocation of the environmental burdens to the different outputs. For example, a sawmill may produce a range of products for different enduses, as well as by-products, such as chippings, bark, sawdust. The LCA practitioner may not be able to divide the energy used for the different operations (for example, there may be one value for electricity demand for the sawmill) and consequently will have to allocate the electricity used between the different products. This allocation could be made on the basis of mass, but this might give an unfair higher impact to low-value products, such as bark. Alternatively, the environmental burdens could be allocated on an economic basis, but this has the disadvantage that prices of different products change with time and with them the associated impacts. Allocation issues are not confined to the timber industry and are commonly encountered in LCA (Jungmeier et al., 2002a,b; Brankatschk and Finkbeiner, 2014).

Aside from the difficulties of obtaining representative GWP values for manufactured products, there are also issues associated with other stages of the lifecycle. The data gathered for the lifecycle inventory for stages A1-A3, is generally the most accurate and reliable, whereas the same cannot always be said for other lifecycle stages. Record keeping for maintenance and replacement, as well as potential recycling, re-use and, cascading and ultimate fate, is rudimentary and often non-existent and for this reason, these stages of the lifecycle are often associated with assumptions and models, rather than supported with hard data. The assumptions that are made in the LCA models can have a profound effect upon the outcomes of the study. For example, the assumption that wood sent to landfill is converted to methane, can have a very large negative impact upon the GWP of timber products, although there is little evidence to show that this is the fate of solid wood products in landfill conditions (Micales and Skog, 1997). LCA comparisons of building structures should compare the same functional unit (with the same operational energy requirements), but this may not be done in order to favor one material choice over another. This makes the use of LCA as a tool to support materials choices in the built environment, problematical. An issue, that is encountered when considering the use of timber in construction, is how to properly account for the use of sequestered atmospheric carbon dioxide in longlife HWPs.

\section{SEQUESTERED CARBON}

Atmospheric carbon is accumulated in living biomass through the process of photosynthesis. This carbon is stored within the living organism and also in the soil through the interactions of roots with organisms in the soil. Most of the carbon of the terrestrial biosphere is stored in forests and Boreal forests store about one third of global terrestrial carbon (Pan et al., 2011; Hovi et al., 2016). It is of major concern that carbon stocks in global forests are decreasing by $1.1 \mathrm{Gt}$ per year, but the carbon pool in European forests is increasing in size by about 365 million tons of sequestered $\mathrm{CO}_{2}$ per year, which is equivalent to $7 \%$ of annual EU emissions (Pilli et al., 2016). Sustainable harvesting of managed forests ensures that the amount of atmospheric carbon that is captured is maximized, otherwise these forests will move into older age classes and carbon sequestration will consequently decline (Nabuurs et al., 1997; Karjalainen et al., 2002). There is therefore an opportunity for increased harvestings in order to improve the carbon sequestration potential of these forests, with the captured carbon being stored for longer periods in HWPs However, old growth non-production forests should be managed for conservation, amenity, ecosystem services, as well as carbon storage (Luyssaert et al., 2008; Newell and Vos, 2012). This is best achieved by the continued, harvesting of managed forests and the 
best approach will prove to be a "mixed" strategy, where some areas are used for HWP production and others for ecosystem services and amenity benefits (Triviño et al., 2016). There is considerable benefit from this management strategy when HWPs are used to substitute for more energy-intensive materials (Poudel et al., 2012), although the benefits of direct use of timber products as an energy source are not so easily demonstrated. The use of HWPs in the built environment has been shown to provide climate change mitigation benefits because of a reduced GWP burden associated with material substitution in comparable functional units; due to the atmospheric carbon storage benefits; and due to the use of processing by-products and end-of-life timber products as an energy source. When examining counterfactuals, where forests are not harvested to produce HWPs, this requires their replacement with more energy- and carbonintensive materials. In addition, the benefits of energy production from the by-products of harvesting, processing and wood waste at the end of lifecycle are lost (Werner et al., 2005).

There has been considerable debate in the LCA community as to how the storage of atmospheric carbon in biogenic materials should be reported and this is an issue that has not been reconciled (Brandão et al., 2013). There have been attempts to construct methods which do incorporate carbon storage into LCA data, but these have all been criticized for various reasons (Vogtländer et al., 2014). The main criticism is that the stored biogenic carbon will eventually re-enter the atmosphere at the end of life of the product and that the net result of such storage is effectively zero. However, it has been recently argued that the storage of biogenic carbon does have a role to play in climate change mitigation and this need to be properly accounted for, even though there is no agreed way of accounting for this in LCA (Tellnes et al., 2017). The issues that need to be addressed are:

- The eventual loss of the stored atmospheric carbon dioxide back to the atmosphere,

- A way of properly accounting for the time of storage of the sequestered carbon,

- A way of differentiating between biogenic carbon released to the atmosphere and fossil carbon released to the atmosphere,

- Comparing the effect of storage of the atmospheric carbon in HWPs compared with the fate of the same carbon if left in the trees in the forest for the same time period (the counterfactual).

These considerations apply not only to the use of biogenic materials in buildings, but also to biofuels (Gustavsson and Sathre, 2011). It has been shown that the storage of atmospheric carbon in long life HWPs has a greater climate change mitigation benefit, when compared with immediate oxidation of the same material for energy recovery (Stewart and Nakamura, 2012), but the use of harvesting and processing residues as an energy source has also been shown to provide benefits, which need to be taken into account when considering the use of timber products for built environment applications by appropriate system expansion of the consequential LCA.

There are considerable difficulties with determining the atmospheric carbon storage benefits in timber products in LCA and it is preferable to record the GWP impact and sequestered carbon independently. This allows for the flows of sequestered carbon into and out of the built environment carbon storage pool to be calculated separately from the substitution benefits of replacing higher impact building materials with timberequivalent functional units. The calculation of such flows requires the availability of accurate inventory data regarding the amount of timber used in buildings and the number of new-builds, as well as the quantity of material which is used in retrofits and refurbishment (Robson et al., 2014). Furthermore, accurate data is needed regarding the lifetime of buildings and timber products therein, in order to model the flows of carbon out of the HWP pool.

The two main approaches for modeling carbon loss from products pools are the single pool and distributed pool methods. In the single pool approach, the rate of loss of carbon from the pool is a function of the total amount of material in the pool, but does not depend on the product lifetimes, whereas with the distributed pool method has a separate pool in the product category for each year of production and the rate of loss is calculated for each year and summed over the period of study, with the rate of removal determined by product age rather than the total stock in the pool. A range of models have been developed to determine the rate of loss of carbon from product pools. One approach to modeling the loss of carbon from the pool is to use assumed half-lives (Braun et al., 2016), but this use of an exponential decay function to model HWP lifetimes is not representative of reality and it has been suggested that this is much better modeled by a probability distribution (Marland et al., 2010; Shirley et al., 2011). Other approaches have included linear (Winjum et al., 1998), Weibull (Thompson and Matthews, 1989; Karjalainen et al., 1994), normal (Muller et al., 2004), and gamma distributions (Klein et al., 2013). An excellent review of this topic is provided by Brunet-Navarro et al. (2016).

\section{THE USE OF TIMBER IN CONSTRUCTION}

It is only relatively recently that the role of HWPs in mitigating greenhouse gas emissions was recognized in the Kyoto Protocol, when the 15th Conference of Parties of the UN Framework Convention on Climate Change agreed that HWPs could be included as an additional carbon pool. However, for the first commitment period (2008-2012), it was assumed that the amount of carbon leaving the HWP pool every year was equal to the annual inflow (instant oxidation). Thus, although a considerable amount of atmospheric carbon could be stored in the HWP pool, this was assumed stable over time and hence there was no net benefit in terms of mitigation potential. This changed for the second commitment period (2013-2020) because it was now permissible to include carbon stock changes in the HWP pool. The IPCC methodologies for reporting gains and losses in carbon pools are divided into three Tiers:

- Tier 1: Simple methods are applied using default values, stock change methods are not permitted and hence instant oxidation is the only way of representing losses from the HWP pool. This means no change in the size of the pool is recorded and 
there is consequently no GHG mitigation benefit from the use of HWPs.

- Tier 2: More specific emission data can be applied, which means the application of first order exponential decay to describe losses from the HWP pool using default values for specified product pools.

- Tier 3: More complex methods can be applied to describe losses from the HWP pool, which can include exponential decay using country-specific factors, or more complex models using distribution curves with time.

Tiers 2 and 3 therefore allow for stock changes to be recorded. For HWPs, the input into different stocks can be estimated from national reporting data, such as that used for the UNFAO statistics. The determination of the quantities of HWPs of different types used in the built environment is challenging and apart from some estimations of material used in newbuild, there is little reliable data of real product lifetimes and especially the amounts of different HWPs used in retrofitting, rebuilds and maintenance. Tracking of material flows through the built environment is a challenge, but assumes greater importance as the desire to understand the true environmental impacts (and potential mitigation activities) associated with the built environment increases. The potential of using HWPs in the built environment as a climate change mitigation strategy has received much attention in the scientific literature (e.g., Jasinevičius et al., 2015; Pilli et al., 2015; BrunetNavarro et al., 2016). Brunet-Navarro et al. (2016) stated that there was a lack of reliable data on the utilization and lifetimes of HWPs to accurately estimate the carbon stocks and fluxes. They concluded by stating "if the sector wants to demonstrate the environmental quality of its products, it should make it a priority to provide reliable lifecycle inventory data, particularly regarding aspects of time and location." Information regarding the lifetimes of buildings and building components is often lacking and many models are therefore based upon assumed lifetimes, often with little justification for those assumptions.

Although the IPCC does recognize the importance of the built environment, the mitigation strategies listed in the fourth and fifth assessment reports (Intergovernmental Panel on Climate Change (IPCC), 2007, 2014) are almost exclusively concerned with energy efficiency measures. Although the use of wood as of a low embodied energy material gets a mention, the potential for HWPs and other biogenic materials to act as carbon stores in the built environment is not considered. Furthermore, the use of mitigation strategies associated with forestry is only concerned with bioenergy and does not discuss the carbon storage potential of timber products. Buildings and building components will be considered in the forthcoming 6th Assessment Report, due in 2021.

The use of HWPs in the built environment allows the carbon storage benefits of timber to be extended beyond the forest (Gustavsson et al., 2006; Liu and Han, 2009; Lehmann and Fitzgerald, 2012; Kremer and Symmons, 2015). In addition, the substitution benefits may have a greater impact on climate change mitigation compared with carbon storage, but they can be difficult to determine (Marland et al., 1997; Werner et al., 2005; Miner and Perez-Garcia, 2007; Matsumoto et al., 2016).

The carbon pool of the built environment can be stable, increasing or decreasing, depending on the rate at which HWPs enter the HWP pool and how quickly the carbon in this pool is oxidized. If the size of the HWP pool is decreasing then more biogenic carbon is being released than is entering, resulting in a concomitant increase of atmospheric radiative forcing (as with the oxidation of fossil fuels). From the point of view of atmospheric carbon dioxide concentration, it is irrelevant whether the source of the carbon is biogenic or fossil. Conversely, an increase in the size of the HWP pool is of benefit for GHG mitigation, since this means there is a net sequestration of atmospheric carbon. However, it is important to consider what is happening to the carbon stocks in the forest from which the timber is obtained, which means that the timber has to come from sustainably managed forests, where felling is no larger than the net annual increment (NAI). If feelings exceed the NAI (which is the annual volume increase in standing timber minus natural losses), then the capital stock of the forest declines. The size of the HWP pool can be increased by harvesting more wood (within the limits of the annual increment) and/or by increasing the service life of wood products in the HWP pool. Further storage benefits are also obtained by cascading the wood down the value chain at the end of the first life of the product. At the end of these multiple product lives the biogenic carbon can be returned to the atmosphere by incineration with energy recovery. Where this energy recovery process substitutes for a fossil fuel energy source, then it is possible to claim additional substitution credits for reducing the emissions of fossil carbon.

The determination of the potential climate change mitigation benefits of using timber in construction requires the consideration of a range of factors, which were summarized by Werner et al. (2006). Because up to twice as much wood material is removed from the forest when timber is used in buildings, it is important to include the fate of these wood by-products in any study (i.e., is this material used for energy, is a proportion left in the forest as soil improvement?). If surplus wood is left in the in the forest after harvesting operations, it is essential to consider the fate of this material with respect to GHG emissions.

When no-harvest counterfactuals are considered, the results are strongly influenced by assumptions made regarding the unharvested forest biomass. It is not sufficient to consider the dynamics of HWP pools in isolation, but consideration must also be given to the dynamics of forest carbon pools. The results that are obtained are very dependent upon the time series and geographical area considered (Koch, 1992). It is important to consider energy and material substitution effects, as well as carbon storage dynamics. With studies that do make proper consideration of both the carbon storage and substitution effects, wood products usually exhibit superior environmental profiles (Werner and Richter, 2007; Gustavsson and Sathre, 2011). However, the results are very strongly dependent upon the selection of an appropriate functional unit, which should be at the building level (Björklund and Tillman, 1997; Lippke et al., 2004; 
Gustavsson et al., 2006), or on the basis of a service ( $1 \mathrm{~m}^{3}$ of living space, or $1 \mathrm{~m}^{2}$ of floor area).

Timber can be used to replace other materials to provide the same functional unit, potentially resulting in a reduction of GWP and embodied energy, with this reduction expressed as a displacement factor (Pingoud et al., 2010). In a meta-analysis of comparisons between timber and non-renewable building construction materials in buildings Sathre and O'Connor (2010) concluded that the average displacement factor was 2.1 (2.1 tons of $\mathrm{CO}_{2}$ e saved per ton of carbon used in the timber product). It was concluded that there was a clear rationale for using timber in construction as a climate change mitigation strategy. Other studies have come to similar conclusions. For example, Petersen and Solberg (2005) found that GHG savings in the range of 36$503 \mathrm{~kg} \mathrm{CO}_{2} \mathrm{e}$ per $\mathrm{m}^{3}$ of timber were achieved by substituting wood for steel and savings between 96 and $1,032 \mathrm{~kg} \mathrm{CO}_{2} \mathrm{e}$ when wood was substituted for concrete.

The quantities of timber that are used to substitute for alternatives vary from study to study. For example, Perez-Garcia et al. (2005a) used a timber to concrete substitution ratio of 1:4 (4 tons of concrete provides the same structural function as 1 ton of wood). Eriksson et al. (2007) and Perez-Garcia et al. (2005b) used real life materials inventories of buildings, whereas Hennigar et al. (2008) used theoretical displacement factors. Sadler (2010) investigated the flow of biogenic carbon into and out of the UK built environment products' pool and the work in his MSc thesis was further developed by Sadler and Robson (undated). According to the model developed by Sadler and Robson (undated) the built environment represents a growing carbon sink due to the use of timber in construction, with 2.5 $\mathrm{Mt} \mathrm{CO}_{2}$ e per year being sequestered if there were no changes in construction techniques. If high biogenic content houses were constructed then the increment in atmospheric carbon storage could potentially be $6 \mathrm{Mt} \mathrm{CO}_{2}$ e per year by 2020 and $10 \mathrm{Mt}$ $\mathrm{CO}_{2}$ e per year by 2030 . The model assumed that 200,000 housing units would be constructed per year. The timber use per $\mathrm{m}^{2}$ that was assumed for this work was taken from a study by Burnett (2006) and is shown in Table 1. Sadler (2010) stated that in the worst-case scenario the disposal of ex-built environment biogenic material to landfill and rapid conversion to methane would negate any benefits arising from carbon storage in the structures.

Monahan and Powell (2011) reported on an LCA study of a 3-bedroom semi-detached house of $91 \mathrm{~m}^{2}$ floor area. The paper compared the GWP impact of a house built using modular timber construction with a conventionally-built structure of the same floor area. They noted that the majority of studies published lacked the level of detail required to make comparisons and had inconsistent system boundaries. The embodied GWP of the timber house was 34.6 tons $\mathrm{CO}_{2} \mathrm{e}\left(405 \mathrm{~kg} \mathrm{CO}_{2}\right.$ e per m${ }^{2}$ of useable floor area), a reduction of $34 \%$ compared to the house built using conventional methods. Even when using the modular timber construction techniques, the most significant contribution to the GWP impact was the use of concrete. They reported that the building contained $4,330 \mathrm{~kg}$ of wood-based composites, $1,315 \mathrm{~kg}$ of larch, $222 \mathrm{~kg}$ of engineered timber and $6,792 \mathrm{~kg}$ of softwood. Based on moisture contents of $20 \%$ for the timber and $10 \%$ for the engineered wood and composites, this gives a dry weight of 10.89 tons of wood. Flack (2015) reported a total of 10.56 tons, since she assigned a moisture content of $20 \%$ to all timber products.

Iddon and Firth (2013) studied a 2 story 4-bedroom house of brick and block construction with a floor area of $166.4 \mathrm{~m}^{2}$. The timber components were studding for the internal walls (192 plus $112 \mathrm{~kg})$, glulam beams $(3,025 \mathrm{~kg})$ floor boards $(1,840 \mathrm{~kg})$, and timber rafters and purlins $(2,023 \mathrm{~kg})$, making a total of 7.19 tons of timber, reducing to 6.22 tons when adjusting for the moisture content. Flack (2015) reported a dry timber weight of 8.2 tons. Flack (2015) reported that there was $71 \mathrm{Mt} \mathrm{C}(260 \mathrm{Mt} \mathrm{CO} 2 \mathrm{e})$ stored in the UK built environment in 2015 and that this would increase to $82.8 \mathrm{Mt} \mathrm{C} \mathrm{(304} \mathrm{Mt} \mathrm{CO}_{2} \mathrm{e}$ ) by 2050 using conventional building methods. As part of the study, an attempt was made to estimate the relationship between the quantity of wood use in construction and the age of the dwelling, showing that more wood was used in older buildings. However, the quality of data used in this study was not good and the conclusions cannot be considered reliable. The value of $71 \mathrm{Mt} \mathrm{C}$ stored in the UK housing stock in 2015 was contrasted with the value calculated by Alexander (1997) of $47 \mathrm{MtC}$ for 1993, the difference being attributed to an increase of 4.3 million homes since then, as well as adjustments to the Flack model to account for timber frame construction. In addition, the Alexander model only looked at wood used in structural applications. The Flack report analyzed the distribution in stored carbon across different age houses as well as regional differences. The report also contained an analysis of the quantities of timber used in house construction, based on other studies and the results are collated in Table $\mathbf{1}$. Flack concluded that the amount of timber used in timber frame properties was 2.8 times that used in a conventional construction for the same floor area. She also found that wood use per unit floor area did not vary significantly across property types, giving confidence to presenting the wood use per unit area as a reliable metric. The weight of timber used was calculated based upon the assumptions that the moisture content was $20 \%$ and the dry wood density was $420 \mathrm{~kg} / \mathrm{m}^{3}$ for post- 1940 constructions.

Arguments have been presented that structural performance is not the only factor that should be considered in a building functional unit. For example, there has been considerable debate about the difference in thermal mass between timber and concrete structures and how this affects the energy performance of a building. The thermal mass is the ability of a building to store heat energy and is important during transient heating and cooling phases of a building, the main contributions to the thermal mass are the building fabric, the air volume and the fixtures and fittings, of which the building fabric is the most important (Reilly and Kinnane, 2017). However, Reilly and Kinnane (2017) note that thermal mass in buildings is an underresearched area and where studies have been performed, they are highly specific and consequently cannot be extrapolated to a whole sector. Many studies of thermal mass neglect the storage time of the heat in the material (thermal inertia) which is an important consideration in the energy performance of a building. Organic materials, such as timber, can store heat for longer than inorganic materials, such as concrete, because the organic materials have a lower thermal conductivity, resulting in a lower thermal diffusivity (Jean et al., 2013). A study comparing timber 
TABLE 1 | Timber use for different building types (UK unless otherwise stated).

\begin{tabular}{|c|c|c|c|c|c|}
\hline Building type & $\begin{array}{l}\text { Timber } \\
\text { use }\left(\mathrm{m}^{3}\right)\end{array}$ & $\begin{array}{l}\text { Timber use } \\
\left(\mathrm{m}^{3} / \mathrm{m}^{2}\right)\end{array}$ & $\begin{array}{l}\text { Timber use } \\
\text { (tons) }\end{array}$ & $\begin{array}{l}\text { Timber use } \\
\left(\mathrm{t} / \mathrm{m}^{2}\right)\end{array}$ & References \\
\hline Small house dwelling (NO) & & 0.30 & & & Hill and Zimmer, 2018 \\
\hline Single family house (NO) & & 0.19 & & & Hill and Zimmer, 2018 \\
\hline Multi-occupancy dwelling (NO) & & 0.03 & & & Hill and Zimmer, 2018 \\
\hline CLT dwelling (NO) & & 0.40 & & & Hill and Zimmer, 2018 \\
\hline Commercial buildings (NO) & & 0.04 & & & Hill and Zimmer, 2018 \\
\hline House (brick and block) & & & & $0.05 \pm 0.01$ & Flack, 2015 \\
\hline House (timber framed) & & & & $0.14 \pm 0.08$ & Flack, 2015 \\
\hline House (brick and block) (166.4m²) & & & 6.22 & 0.037 & Iddon and Firth, 2013 \\
\hline Detached (brick and block) & & & 8.26 & 0.064 & Cuéllar-Franca and Azapagic, 2012 \\
\hline Semi-detached (brick and block) & & & 6.08 & 0.068 & Cuéllar-Franca and Azapagic, 2012 \\
\hline Terraced (brick and block) & & & 3.88 & 0.065 & Cuéllar-Franca and Azapagic, 2012 \\
\hline $\begin{array}{l}\text { Semi-detached (timber framed and clad) } \\
\left(91 \mathrm{~m}^{2}\right)\end{array}$ & & & 10.89 & 0.119 & Monahan and Powell, 2011 \\
\hline Traditional house (brick and block) $\left(88 \mathrm{~m}^{2}\right)$ & & & 3.52 & 0.04 & Sadler, 2010 \\
\hline House (timber frame, brick clad) $\left(88 m^{2}\right)$ & & & 5.28 & 0.06 & Sadler, 2010 \\
\hline House (timber frame, timber clad) $\left(88 \mathrm{~m}^{2}\right)$ & & & 7.92 & 0.09 & Sadler, 2010 \\
\hline High biogenic $\left(88 \mathrm{~m}^{2}\right)$ & & & 17.6 & 0.2 & Sadler, 2010 \\
\hline Detached house (brick and block) & 7.09 & & & & Prebble, 2007 \\
\hline Mid-size dwelling (brick and block) & 4.96 & & & & Prebble, 2007 \\
\hline Multi-occupancy (brick and block) & 2.84 & & & & Prebble, 2007 \\
\hline Detached house (timber frame) & 10.45 & & & & Prebble, 2007 \\
\hline Mid-size dwelling (timber frame) & 7.32 & & & & Prebble, 2007 \\
\hline Flat (timber frame) & 4.18 & & & & Prebble, 2007 \\
\hline Semi-detached (timber frame) & & & 5.68 & 0.081 & Asif et al., 2007 \\
\hline Detached (brick and block) & & & 3.89 & 0.039 & Burnett, 2006 \\
\hline Semi-detached (brick and block) & & & 2.02 & 0.036 & Burnett, 2006 \\
\hline Multi-occupancy (brick and block) & & & 12.82 & 0.025 & Burnett, 2006 \\
\hline Detached (timber framed) & & & 10.24 & 0.104 & Burnett, 2006 \\
\hline Semi-detached (timber framed) & & & 5.02 & 0.090 & Burnett, 2006 \\
\hline Multi-occupancy (timber framed) & & & 40.85 & 0.077 & Burnett, 2006 \\
\hline Multi-occupancy (brick and block) (SE) & & & 79.20 & 0.1 & Gustavsson et al., 2006b \\
\hline Multi-occupancy (timber frame) (SE) & & & 156.00 & 0.1 & Gustavsson et al., 2006b \\
\hline
\end{tabular}

A density of $420 \mathrm{~kg} / \mathrm{m}^{3}$ has been used.

frame and concrete construction in a Scandinavian context found that there was relatively little saving in energy demand in a concrete building due to the thermal inertia of the material. The magnitude of the operational energy saving was smaller than the amount of energy recovered from the wood processing residues, end of life wood wastes from the building and the lower embodied energy of the wood material used in construction compared to the concrete (Dodoo et al., 2012).

\section{END OF LIFE OF HWPS}

The lifetime of timber products in the built environment is difficult to predict with certainty and depends upon a number of factors. At the present time, the source for service life information is based on the durability classes (DC) listed for different untreated wood species in EN 350 (2016) plus national lists, where they exist, However, the durability class classification only indicates a ranking between materials, but does not provide information about years of service expected before failure. This can vary significantly depending upon natural variation in the wood properties, design factors in the building (such as moisture traps), climatic factors (primarily temperature and moisture), maintenance, and aesthetic factors including fashion, There are recommended lifetimes (or decay half-lives) that can be applied to different timber products, but these do not accurately represent the situation on the ground and there is an urgent need to establish the true service lives of timber products in the built environment in different climatic zones.

At the end of life, the timber product can be incinerated with or without energy recovery, re-used, cascaded down to a lower value product (also called down-cycling), or disposed to landfill (although this is no longer an option for many countries) (Krook et al., 2004; Carpenter et al., 2013). The ultimate fate of demolition materials is not always known with certainty and even less is known about materials disposed of during retrofit, refurbishment or other building modifications. 
Tracking the flows of carbon out of the built environment pool is problematical, but modeling the different impacts associated with ultimate fate is even more so. There is a consensus that keeping HWPs in product pools for as long as possible is generally beneficial and cascading is claimed to result in a lower impact compared with incineration and return of the stored carbon to the atmosphere (Haberl and Geissler, 2000; Höglmeier et al., 2014; Taskhiri et al., 2016). However, the potential benefits of cascading compared with incineration with energy recovery depend strongly on the details of the analysis and the counterfactuals chosen. The benefits of replacement of a fossil fuel source for example depend very much upon the fuel chosen for the analysis (coal, oil, or methane). Although the LCA may prove favorable, cascading is only viable when there is sufficient available processing capacity and adequate demand for the products made from wood waste. The presence of preservative-treated wood in waste wood streams is an issue that must be addressed potentially requiring investment in technology to sort different waste streams.

There has been much debate about the fate of timber products in landfill and when it is assumed that all of the carbon content in landfilled timber is converted to methane then very unfavorable environmental impacts are obtained. These assumptions are invariably based on laboratory studies of the decomposition of wood under anaerobic conditions. In fact, very little is known about the degradation of wood products under landfill conditions (Barlaz, 2006) and in some studies it is assumed that landfilling of wood can provide GHG mitigation benefits due to long term carbon storage. For example in a study by Christensen et al. (2009) it was estimated there was a GHG offset of $141-261 \mathrm{~kg}$ $\mathrm{CO}_{2}$ e per ton of wood waste disposed. Karjalainen et al. (1994) calculated that the amount of original carbon stored in timber products and in landfills after a century was one third of the

\section{REFERENCES}

Alexander, M. (1997). Estimation of national carbon stocks and fluxes of wood-based products (MSc thesis). University of Surrey, Guildford, United Kingdom.

Asif, M., Muneer, T., and Kelley, R. (2007). Life cycle assessment: a case study of a dwelling home in Scotland. Build. Environ. 42, 1391-1394. doi: 10.1016/j.buildenv.2005.11.023

Barlaz, M. (2006). Forest products decomposition in municipal solid waste landfills. Waste Manage. 26, 321-331. doi: 10.1016/j.wasman.2005.11.002

Björklund, T., and Tillman, A.-M. (1997). LCA of Building Frame Structures: Environmental Impact Over the Life Cycle of Wooden and Concrete Frames. Technical Environmental Planning Report. Chalmers University of Technology.

Brandão, M., Levasseur, A., Kirschbaum, M., Weidema, B., Cowie, A., Jørgensen, S., et al. (2013). Key issues and options in accounting for carbon sequestration and tempory storage in life cycle assessment and carbon footprinting. Int. J. Life Cycle Assess. 18, 230-240. doi: 10.1007/s11367-012-0451-6

Brankatschk, G., and Finkbeiner, M. (2014). Application of the cereal unit in a new allocation procedure for agricultural life cycle assessments. J. Clean. Product. 73, 72-79. doi: 10.1016/j.jclepro.2014.02.005

Braun, M., Winner, G., Schwarzbauer, P., and Stern, T. (2016). Apparent half-lifedynamics of harvested wood products (HWPs). in Austria: development and analysis of weighted time-series for 2002 to 2011. For. Policy Econo. 63, 28-34. doi: 10.1016/j.forpol.2015.11.008 original amount. Although the IPCC recommend a default value of $50 \%$ as the fraction of degradable carbon in landfilled wood field studies have shown that this is actually $<50 \%$ (Micales and Skog, 1997; De la Cruz et al., 2013; Wang et al., 2013). Disposal of waste wood to landfill is prohibited in Europe and it must either be incinerated or reused.

\section{CONCLUSIONS}

Timber derived from sustainably managed plantation forests can be used in long-life products in the built environment as a climate change mitigation measure. For a comparable functional unit, timber has a lower embodied energy and GWP impact compared with other materials and there is the additional benefit of the storage of carbon sequestered from atmospheric carbon dioxide. Cascading of the timber through multiple lives ensures that this carbon is stored for longer and there are usually additional benefits obtained in terms of a reduced GWP impact when recycled wood is used in preference to virgin wood, especially related to the reduced drying requirements. Final disposal of the wood by incineration and energy recovery returns the carbon dioxide to the atmosphere at some point in the future and there are benefits to be gained if there is substitution of a fossil fuel energy source. Sequestered atmospheric carbon should be treated separately from GWP impact, since the climate change mitigation benefits of atmospheric carbon storage are only realized when a carbon pool is filling.

\section{AUTHOR CONTRIBUTIONS}

The author confirms being the sole contributor of this work and has approved it for publication.
Bribián, I., Capilla, A., and Usón, A. (2011). Life cycle assessment of building materials: comparative analysis of energy and environmental impacts and evaluation of the eco-efficiency improvement potential. Build. Environ. 46, 1133-1140. doi: 10.1016/j.buildenv.2010.12.002

Broun, R., and Menzies, G. (2011). Life cycle energy and environmental analysis of partition wall systems in the UK. Proced. Eng. 21, 864-873. doi: 10.1016/j.proeng.2011.11.2088

Brunet-Navarro, P., Jochheim, H., and Muys, B. (2016). Modelling carbon stocks and fluxes in the wood product sector: a comparative review. Glob. Change Biol. 22, 2555-2569. doi: 10.1111/gcb.13235

Burnett, J. (2006). Greenhouse Gas Emissions - Carbon Benefits of Timber in Construction. Edinburgh: Edinburgh Centre for Carbon Management.

Carpenter, A., Jambeck, J., and Gardner, K. (2013). Life cycle assessment of endof-life management options for construction and demolition debris. J. Industr. Ecol. 17, 396-406. doi: 10.1111/j.1530-9290.2012.00568.x

Chau, C., Leung, T., and Ng, W. (2015). A review on life cycle assessment, lifecycle energy assessment and life cycle carbon emissions assessment on buildings. Appl. Energy 143, 395-413. doi: 10.1016/j.apenergy.2015.01.023

Christensen, T., Simion, F., Tonini, D., and Moller, J. (2009). Global warming factors modelled for 40 generic municipal waste management scenarios. Waste Manage. Res. 27, 871-884. doi: 10.1177/0734242X09350333

Cuéllar-Franca, R., and Azapagic, A. (2012). Environmental impacts of the UK residential sector: Life cycle assessment of houses. Build. Environ. 54 86-99 doi: 10.1016/j.buildenv.2012.02.005 
De la Cruz, F., Chanton, J., and Barlaz, M. (2013). Measurement of carbon storage in landfills from the biogenic carbon content of excavated waste samples. Waste Manage. 33, 2001-2005. doi: 10.1016/j.wasman.2012.12.012

De Schepper, M., Van den Heede, P., Van Driessche, I., and De Belie, N. (2014). Lie cycle assessment of completely recyclable concrete. Materials 7, 6010-6027. doi: 10.3390/ma7086010

Dixit, M., Fernández-Solís, J., Lavy, S., and Culp, C. (2012). Need for an embodied energy measurement protocol for buildings: a review. Renew. Sustain. Energy Rev. 16, 3730-3743. doi: 10.1016/j.rser.2012.03.021

Dodoo, A., Gustavsson, L., and Sathre, R. (2012). Effect of thermal mass on life cycle primary energy balances of a concrete- and a wood-frame building. Appl. Energy 92, 462-472. doi: 10.1016/j.apenergy.2011.11.017

EN 15804 (2012). Sustainability of Construction Works - Environmental Product Declarations - Core Rules for the Product Category of Construction Products.

EN 350 (2016). Durability of Wood-Based Products. Testing and Classification of the Durability to Biological Agents of Wood and Wood-Based Materials.

Eriksson, E., Gillespie, A., Gustavsson, L., Langvall, O., Olsson, M., Sathre, R., et al. (2007). Integrated carbon analysis of forest management practices and wood substitution. Canad. J. For. Res. 37, 671-681. doi: 10.1139/X06-257

Fay, R., Treloar, G., and Iyer-Raniga, U. (2000). Life-cycle analysis of buildings: a case study. Build. Res. Inform. 28, 31-41. doi: 10.1080/096132100369073

Flack, S. (2015). Investigating Wood Use in UK Construction. Forestry Commission Internal Report.

Gustavsson, L., Pingoud, K., and Sathre, R. (2006). Carbon dioxide balance in wood substitution: comparing concrete and wood framed buildings. Mitigat. Adapt. Strate. Glob. Change 11, 667-691. doi: 10.1007/s11027-006-7207-1

Gustavsson, L., and Sathre, R. (2011). Energy and $\mathrm{CO}_{2}$ analysis of wood substitution in construction. Clim. Change 105, 129-153. doi: $10.1007 / \mathrm{s} 10584-010-9876-8$

Haberl, H., and Geissler, S. (2000). Cascade utilization of biomass: strategies for a more efficient use of a scarce resource. Ecol. Eng. 16, S111-S121. doi: 10.1016/S0925-8574(00)00059-8

Hammond, G., and Jones, C. (2008). Embodied energy and carbon in construction materials. Proc. Inst. Civil Eng. Energy 161, 87-98. doi: 10.1680/ener.2008.161.2.87

Hennigar, C., MacLean, D., and Amos-Binks, L. (2008). A novel approach to optimize management strategies for carbon stored in both forests and wood products. For. Ecol. Manage. 256, 786-797. doi: 10.1016/j.foreco.2008.05.037

Hill, C., and Zimmer, K. (2018). The Environmental Impact of Wood Compared to Other Building Materials. NIBIO Report 4. Available online at: https://brage. bibsys.no/xmlui/handle/11250/2496052 (accessed 13/03/2018)

Höglmeier, K., Weber-Blaschke, G., and Richter, K. (2014). Utilization of recovered wood in cascades versus utilization of primary wood - a comparison with life cycle assessment using system expansion. Int. J. Life Cycle Assess. 19, 1755-1766. doi: 10.1007/s11367-014-0774-6

Hovi, A., Liang, J., Korhonen, L., Kobayashi, H., and Rautiainen, M. (2016). Quantifying the missing link between forest albedo and productivity in the boreal zone. Biogeosciences 13, 6015-6030. doi: 10.5194/bg-13-6015-2016

Iddon, C., and Firth, S. (2013). Embodied and operational energy for new-build housing: a case study of construction methods in the UK. Energy Buil. 67, 479-488. doi: 10.1016/j.enbuild.2013.08.041

Intergovernmental Panel on Climate Change (IPCC) (2007). Fourth Assessment Report. Cambridge University Press.

Intergovernmental Panel on Climate Change (IPCC) (2014). Fifth Assessment Report. Cambridge University Press.

Jasinevičius, G., Linder, M., Pingoud, K., and Tykkylainen, M. (2015). Review of models for carbon accounting in harvested wood products. Int. Wood Product J. 6, 198-212. doi: 10.1080/20426445.2015.1104078

Jean, A., Olives, R., and Py, X. (2013). Selection criteria of thermal mass materials for low-energy building construction applied to conventional and alternative materials. Energy Build. 63, 36-48. doi: 10.1016/j.enbuild.2013.03.047

Jungmeier, G., Werner, F., Jarnehammer, A., Hohenthal, C., and Richter, K. (2002a). Allocation in LCA of wood-based products - experiences of COST action E9 part 1. Methodology. Int. J. Life Cycle Assess. 7, 290-294. doi: $10.1007 / \mathrm{BF} 02978890$

Jungmeier, G., Werner, F., Jarnehammer, A., Hohenthal, C., and Richter, K. (2002b). Allocation in LCA of wood-based products - experiences of
COST action E9 part 2. Examples. Int. J. Life Cycle Assess. 7, 369-375. doi: $10.1007 / \mathrm{BF} 02978686$

Karjalainen, T., Kellomaki, S., and Pussinen, A. (1994). Role of wood-based products in absorbing carbon atmospheric carbon. Silva Fennica 28, 67-80.

Karjalainen, T., Pussinen, A., Liski, J., Nabuurs, G.-J., Erhard, M., Eggers, T., et al. (2002). An approach towards an estimate of the impact of forest management and climate change on the European forest sector carbon budget: Germany as a case study. For. Ecol. Manage. 162, 87-103. doi: 10.1016/S0378-1127(02)00052-X

Klein, D., Höllerl, S., Blaschke, M., and Schulz, C. (2013). The contribution of managed and unmanaged forests to climate change mitigation - a model approach at stand level for the main tree species in Bavaria. Forests 4, 43-69. doi: 10.3390/f4010043

Koch, P. (1992). Wood versus nonwood materials in US residential construction: some energy related implications. For. Products J. 42, 31-42.

Kotaji, S., Edwards, S., and Schuurmans, A. (2003). Life Cycle Assessment in Building and Construction. A State-of-the-Art Report. SETAC Press.

Kremer, P., and Symmons, M. (2015). Mass timber construction as an alternative to concrete and steel in the Australia building industry: a PESTEL evaluation of the potential. Int. Wood Products J. 6, 138-147. doi: 10.1179/2042645315Y.0000000010

Krook, J., Mårtensson, A., and Eklund, M. (2004). Metal contamination in recovered waste wood used as energy source in Sweden. Resour. Conserv. Recycling 41, 1-14. doi: 10.1016/S0921-3449(03)00100-9

Langston, Y., and Langston, C. (2008). Reliability of building embodied energy modelling: an analysis of 30 Melbourne case studies. Construct. Manage. Econo. 26, 147-160. doi: 10.1080/01446190701716564

Lehmann, S., and Fitzgerald, G. (2012). Sustainable urban infill development using low carbon prefabricated timber construction. Sustainability 4, 2707-2742. doi: $10.3390 /$ su4102707

Lenzen, M. (2008). Life cycle energy and greenhouse gas emissions of nuclear energy: a review. Energy Conver. Manage. 49, 2178-2199. doi: 10.1016/j.enconman.2008.01.033

Lippke, B., Wilson, J., Perez-Garcia, J., Bowyer, J., and Meil, J. (2004). CORRIM: life-cycle environmental performance of renewable building materials. For. Products J. 54, 8-19.

Liu, G., and Han, S. (2009), Long-term forest management and timely transfer of carbon into wood products help reduce atmospheric carbon. Ecol. Modell. 220, 1719-1723. doi: 10.1016/j.ecolmodel.2009.04.005

Luyssaert, S., Schulze, E., Börner, A., Knohl, A., Hessenmöller, D., Law, B., et al. (2008). Old-growth forests as global carbon sinks. Nature 455, 213-215. doi: $10.1038 /$ nature 07276

Marland, E., Stellar, K., and Marland, G. (2010). A distributed approach for carbon in wood products. Mitigat. Adapt. Strate. Glob. Change 15, 71-91. doi: 10.1007/s11027-009-9205-6

Marland, G., Schlamadinger, B., and Canella, L. (1997). Forest management for the mitigation of $\mathrm{CO}_{2}$ emissions: how much mitigation and who gets the credits? Mitigat. Adapt. Strate. Glob. Change. 2, 303-318.

Matsumoto, M., Oka, H., Mitsuda, Y., Hashimoto, S., Kayo, C., Tsunetsugu, Y., et al. (2016). Potential contributions of forestry and wood use to climate change mitigation in Japan. J. For. Res. 21, 211-222. doi: 10.1007/s10310-0160527-4

Micales, J., and Skog, K. (1997). The decomposition of forest products in landfills. Int. Biodeterior. Biodegrad. 39, 145-158. doi: 10.1016/S0964-8305(97)83389-6

Miner, R., and Perez-Garcia, J. (2007). The greenhouse gas and carbon profile of the global forest products industry. For. Products J. 57, 80-90.

Monahan, J., and Powell, J. (2011). An embodied carbon and energy analysis of modern methods of construction in housing: A case study using a lifecycle assessment framework. Energy Build. 43, 179-188. doi: 10.1016/j.enbuild.2010.09.005

Morel, J., Mesbah, A., Oggero, M., and Walker, P. (2001). Building houses with local materials: means to drastically reduce the environmental impact of construction. Build. Environ. 36, 1119-1126. doi: 10.1016/S0360-1323(00)00054-8

Muller, D., Bader, H.-P., and Baccini, P. (2004). Long term coordination of timber production and consumption using a dynamic material and energy flow analysis. J. Industr. Ecol. 8, 65-87. doi: 10.1162/1088198042442342 
Nabuurs, G., Päivinen, R., Sikkema, R., and Mohren, G. (1997). The role of European forests in the global carbon cycle - a review. Biomass Bioenergy 13, 345-358. doi: 10.1016/S0961-9534(97)00036-6

Nässén, J., Holmberg, J., Wadeskog, A., and Nyman, M. (2007). Direct and indirect energy use and carbon emissions in the production phase of buildings: an input-output analysis. Energy 32, 1593-1602. doi: 10.1016/j.energy.2007.01.002

Newell, J., and Vos, R. (2012). Accounting for forest carbon pool dynamics in product carbon footprints: challenges and opportunities. Environ. Impact Assess. Rev. 37, 23-36. doi: 10.1016/j.eiar.2012.03.005

Oka, T., Suzuki, M., and Konnya, T. (1993). The estimation of energy consumption and amount of pollutants due to the construction of buildings. Energy Build. 19, 303-311. doi: 10.1016/0378-7788(93)90016-N

Pan, Y., Birdsey, R., Fang, J., Houghton, R., Kauppi, P., Kurz, W., et al. (2011). A large and persistent carbon sink in the world's forests. Science 333, 988-993. doi: 10.1126/science.1201609

Perez-Garcia, J., Lippke, B., Briggs, D., Wilson, J., Boyer, J., and Meil, J. (2005a). The environmental performance of renewable building materials in the context of residential construction. Wood Fiber Sci. 37, 3-17.

Perez-Garcia, J., Lippke, B., Comnick, J., and Manriquez, C. (2005b). An assessment of carbon pools, storage, and wood products market substitution using life-cycle analysis results. Wood Fiber Sci. 37, 140-148.

Petersen, A., and Solberg, B. (2005). Environmental and economic impacts of substitution between wood products and alternative materials: a review of micro-level analyses from Norway and Sweden. For. Policy Econo. 7, 249-259. doi: 10.1016/S1389-9341(03)00063-7

Pilli, R., Fiorese, G., and Grassi, G. (2015). EU mitigation potential of harvested wood products. Carbon Balance Manage. 10:6. doi: 10.1186/s13021-015-0016-7

Pilli, R., Grassi, G., Kurz, W., Moris, J., and Viñas, R. (2016). Modelling forest carbon stock changes as affected by harvest and natural disturbances. II. EUlevel analysis. Carbon Balance Manage. 11:20. doi: 10.1186/s13021-016-0059-4

Pingoud, K., Pohjola, J., and Valsta, L. (2010). Assessing the integrated climatic impacts of forestry and wood products. Silva Fennica 44, 155-175. doi: 10.14214/sf.166

Poudel, B., Sathre, R., Bergh, J., Gustavsson, L., Lundström, A., and Hyvonen, R. (2012). Potential effects of intensive forestry on biomass production and total carbon balance in north-central Sweden. Environ. Sci. Policy 15, 106-124. doi: 10.1016/j.envsci.2011.09.005

Prebble, C. (2007). Establishing the Use of Wood Products in Construction to Assess Their Potential Contribution to Scotland's Carbon Emissions' Reduction Target. Unpublished Report for Forestry Commission Scotland.

Ramesh, T., Prakash, R., and Shukla, K. (2010). Life cycle energy analysis of buildings: an overview. Energy Build. 42, 1592-1600. doi: 10.1016/j.enbuild.2010.05.007

Reilly, A., and Kinnane, O. (2017). The impact of thermal mass on building energy consumption. Appl. Energy 198, 108-121. doi: 10.1016/j.apenergy.2017.04.024

Robson, D., Sadler, P., and Newman, G. (2014). Carbon sequestered in UK forest products and wood based panels in construction: helping to meet UK's greenhouse gas emission reduction targets. Int. Wood Products J. 5, 139-145. doi: 10.1179/2042645314Y.0000000071

Sadler, P. (2010). Biogenic materials for housing, a climate change mitigation strategy (MSc thesis). Oxford Brookes University, Oxford, United Kingdom.

Sadler, P., and Robson, D. (undated). Carbon Sequestration by Buildings. https:// asbp.org.uk/wp-content/uploads/2016/07/ASBP_Carbon-sequestration-bybuildings.pdf (accessed March 13, 2019).

Sathre, R., and O'Connor, J. (2010). Meta-analysis of greenhouse gas displacement factors of wood product substitution. Environ. Sci. Policy 13, 104-114. doi: 10.1016/j.envsci.2009.12.005

Shirley, K., Marland, E., Cantrell, J., and Marland, G. (2011). Managing the cost of emissions for durable, carbon-containing products. Mitigat. Adapt. Strate. Glob. Change 16, 325-346 doi: 10.1007/s11027-010-9268-4
Smil, V. (2007). Energy in Nature and Society: General Energetics of Complex Systems. Cambridge: MA: MIT Press.

Stewart, W., and Nakamura, G. (2012). Documenting the full climate benefits of harvested wood products in Northern California: linking harvests to the US greenhouse gas inventory. For. Products J. 62, 340-353. doi: 10.13073/0015-7473-62.5.340

Suttie, E., Taylor, G., Livesey, K., and Tickell, F. (2009). "Potential of forest products and substitution for fossil fuels to contribute to mitigation," in Combating Climate Change - A Role for UK Forests, eds D. Read, P. Freer-Smith, J. Morison, N. Hanley, C. West, and P. Snowdon (Edinburgh: The Stationary Office), 119-138.

Taskhiri, M., Garbs, M., and Geldermann, J. (2016). Sustainable logistics network for wood flow considering cascade utilisation. J. Clean. Product. 110, 25-39. doi: 10.1016/j.jclepro.2015.09.098

Tellnes, L., Ganne-Chedeville, C., Dias, A., Dolezal, F., Hill, C., and Escamilla, E. (2017). Comparative assessment for biogenic carbon accounting methods in carbon footprint of products: a review study for construction materials based on forest products. iForest 10, 815-823. doi: 10.3832/ifor 2386-010

Thompson, D., and Matthews, R. (1989). $\mathrm{CO}_{2}$ in trees and timber lowers the greenhouse effect. For. Br. Timber 18, 19-24.

Treloar, G., Love, E., and Holt, G. (2001). Using national input-output data for embodied energy analysis of individual residential buildings. Construct. Manage. Econo. 19, 49-61. doi: 10.1080/014461901452076

Triviño, M., Pohjanmies, T., Mazziotta, A., Juutinen, A., Podkopaev, D., Tortorec, E., et al. (2016). Optimizing management to enhance multifunctionality in a boreal forest landscape. J. Appl. Ecol. 54, 61-70. doi: 10.1111/1365-2664. 12790

Vogtländer, J., van der Velden, N., and van der Lugt, P. (2014). Carbon sequestration in LCA, a proposal for a new approach based on the global carbon cycle; cases on bamboo and wood. Int. J. Life Cycle Assess. 19, 13-23. doi: 10.1007/s11367-013-0629-6

Wang, X., Padgett, J., Powell, J., and Barlaz, M. (2013). Decomposition of forest products buried in landfills. Waste Manage. 33, 2267-2276. doi: 10.1016/j.wasman.2013.07.009

Werner, F., and Richter, K. (2007). Wooden building products in comparative LCA - a literature review. Int. J. Life Cycle Assess. 12, 470-479. doi: $10.1065 / \mathrm{lca} 2007.04 .317$

Werner, F., Taverna, R., Hofer, P., and Richter, K. (2005). Carbon pool and substitution effects of an increased use of wood in buildings in Switzerland: first estimates. Ann. For. Sci. 62, 889-902. doi: 10.1051/forest:20 05080

Werner, F., Taverna, R., Hofer, P., and Richter, K. (2006). Greenhouse gas dynamics of an increased use of wood in buildings in Switzerland. Clim. Change 74, 319-347. doi: 10.1007/s10584-006-0427-2

Winistorfer, P., Chen, Z., Lippke, B., and Stevens, N. (2005). Energy consumption and greenhouse gas emissions related to the use, maintenance, and disposal of a residential structure. Wood Fiber Sci. 37, 128-139.

Winjum, J., Brown, S., and Schlamadinger, B. (1998). Forest harvests and wood products sources and sinks of atmospheric carbon dioxide. For. Sci. $44,272-284$.

Conflict of Interest: $\mathrm{CH}$ is a director of JCH Industrial Ecology Limited.

Copyright (c) 2019 Hill. This is an open-access article distributed under the terms of the Creative Commons Attribution License (CC BY). The use, distribution or reproduction in other forums is permitted, provided the original author(s) and the copyright owner(s) are credited and that the original publication in this journal is cited, in accordance with accepted academic practice. No use, distribution or reproduction is permitted which does not comply with these terms. 